\title{
Characterization and performance evaluation of white, Silver Bezoar and Black coated type of Black Bengal Goat in Bangladesh
}

\author{
S. A. Siddiqua and M. Ruhul Amin \\ Department of Animal Breeding and Genetics, Bangladesh Agricultural University, Mymensingh- 2202, Bangladesh
}

\begin{abstract}
The study was undertaken to know the distribution pattern, morphometric characteristics, production and reproduction peculiarities of White, Silver Bezoar and Black coated types of Black Bengal goat in Sylhet, Mymensingh and Bogra region of Bangladesh. Live weight, body measurements, hair diameter and density per unit area were directly obtained from animals. Milk production, life span, number of kidding and other behavioural data (0-5 score) were collected by interviewing farmers The proportion of White type linearly decreased from east (30\% in Sylhet) to west $(18 \%$ in Bogra) but an erratic fashion was observed in Silver Bezoar type. White type was significantly ( $<<0.001)$ heavier at 3, 6, 9 and 12 month among the groups. Body length behaved similarly although heart girth and height at wither showed irregular pattern between groups. White goat possessed coarser but Black goat had more dense $(p<0.01)$ hair at flank and thigh. Herding tendency, resting in crowdy place, grazing habit $(p<0.001)$ of White type was higher than its contemporaries. Average milk yield ( $g / d a y)$ was higher $(p<0.05)$ in White type $(366.84)$ than Black (248.83) and Silver Bezoar types (274.16). Above findings suggest that White and Silver Bezoar types of Black Bengal goat are superior to Black coated goats and thus demand due attention in order for their conservation. Further study is needed for genetic characterization for final recommendation.
\end{abstract}

Keywords: Black Bengal goat, White type, Silver Bezoar type, Coat color, Hair density

\section{Introduction}

Black Bengal (BB) is the only breed of goat constituting a population size of 34.50 million $(F A O, 2003)$ and distributed all over Bangladesh. These goats are of particular economic significance in the subsistence farming of rural community. Goats have been aptly said to be "poor man's cow" as they are living resort for poverty alleviation particularly in subsistence level of farming for many small and landless farmer families (Amin, 2000). Paradoxical to the breed name Black Bengal is not always solid black in coat color rather in this breed coat color polymorphism does exit. These are i. Full white or cream, ii. Bezoar, iii. Silver Bezoar, iv. Solid Black, v. Black with "Toggenburg pattern" of spotting, vi. Black with "Dutch belt" spotting (Nozawa et al., 1984; Alam, 2006 and Faruque and Khandoker, 2007). According to Nozawa et al (1984) at least four loci (I, A, D, S) are involved in this polymorphism (Nozawa et al., 1984). Amongst them Black, White (Cream) and Silver Bezoar coat color patterns are very frequent (Faruque and Khandokar, 2007). These coat color types might have some unique features and adaptive advantages to pertinent habitat. The world's livestock production is increasingly based on a limited number of breeds. Genetic diversity within these breeds also in declining mode. There is also evidence to suggest that, population that are genetically diverse in terms of their disease resistance characteristics are less susceptible to large scale disease epidemics (FAO, 2007). In spite of having values, these indigenous FAnGRs in many cases have been prejudiced and pushed under threatening situation. FAO's initiatives towards exploration and conservation of indigenous livestock genetic resources are seriously underway. It is reported that almost one breed of domestic animal disappeared per month during 20002006 and around $20 \%$ of the reported breeds are classified at risk (FAO, 2007). Under these circumstances, it has become crucial to explore the coat color based sub- population of BB goats to have a better understanding on them and finally focusing such FAnGR on the global stream of literature. Effective management, planned breeding and in-situ conservation programme with these goats are to be prioritized among the activities related to their development (Husain and Amin, 2003). In spite of having promises of White and Silver Bezoar types of BB goats amongst the world goat genetic resource, no substantial work has yet been done on their evaluation and characterization. The present study was thus aimed to explore habitat, distribution pattern, physical characterization and performance evaluation of White, Silver Bezoar (SB) and Black type of BB goats in Sylhet, Mymensingh and Bogra district of Bangladesh. To characterize White and SB types of goats and evaluate their productive performances, comparison was made taking Black coated goats as the control group. 


\section{Materials and Methods}

The field investigation was carried out over a period from July, 2007 to June, 2008 in some villages which were chosen randomly from the three different regions of Bangladesh, namely Sylhet, Mymensingh, and Bogra. For collecting field data, two approaches were adopted viz. i) recording live weight and body measurements taken directly from animal and ii) surveying population and gathering farmers' opinions accomplished through interviewing goat owners door to door. Amongst various coat color groups of the BB breed three types such as White, Silver Bezoar (SB) (black line of hair over the spinous process, legs, and heads on white background) and Black goat (photograph 1, 2 and 3, respectively) were envisaged for the present study. The Black goats were used as control group for making any sort of comparison with other types to be tested. For enumeration of hair density per sq. inch in flank and thigh region a $1 \mathrm{sq}$. inch transparent glass piece was placed on a priorly shaved area to visualize the root of the hair follicle each time. Number of hair follicles in the given area directly gave the hair density per sq. inch. again each hair diameter was measured by averaging three readings in three regions of a hair under compound microscope using micrometer (Alam, 2006). Average milk yield /day were estimated adjusting records for lactation order and stage of lactation by additive correction method. Behavior of goats as objective traits were classed to vary from $0-5$, where 0 and 5 indicate absence of particular behavior and maximum degree of that behavior, respectively. Such objective traits included herding tendency, rain bath, resting in crowdy place, foraging habit, stocking density, pre-weaning mortality, disease susceptibility, and maximum life span. Analyses of variances (ANOVA) and multiple comparison of means were performed using Statistical Package for Social Science (SPSS) of version 7.5. The pertinent statistical model was

$Y_{\mathrm{ijk}}=\mu+R_{\mathrm{i}}+C_{\mathrm{j}}+\mathrm{S}_{\mathrm{k}}+\mathrm{e}_{\mathrm{ijk}}$

Where $Y_{i j k}=$ observation, $\mu$ = general mean, $R_{i}=$ effect of $i$-th region, $C_{j}=$ effect of $j$-th coat colour, $S_{k}=$ effect k-th sex, $e_{\mathrm{ijk}}=$ random error with mean'0' and variance ó ${ }^{2} \mathrm{e}$

\section{Results and Discussion}

\section{Distribution pattern of goats}

Distribution pattern of different coat color types of BB goat in the experimental sites is shown in Fig. 1. A linearly decreasing trend for White type goat was found from east (Sylhet $30 \%$ ) to west (Bogra $18 \%$ ) in the study area although an erratic fashion of distribution was noted for Silver Bezoar type ranging from 13 to $15 \%$ in the same experimental sites. Among Black, Brown, Dutch Belt, White and Silver Bezoar types relative proportion (\%) of Black, White and SB types in Sylhet, Mymensingh and Bogra were 37, 30 and 13, 54,26 and 7 and 44,18 and 15, respectively (Fig. 1). This distribution pattern may be attributed to farmers' preference, availability of breeding bucks, survival differences, market factors and agro-ecology pertinent to habitat.

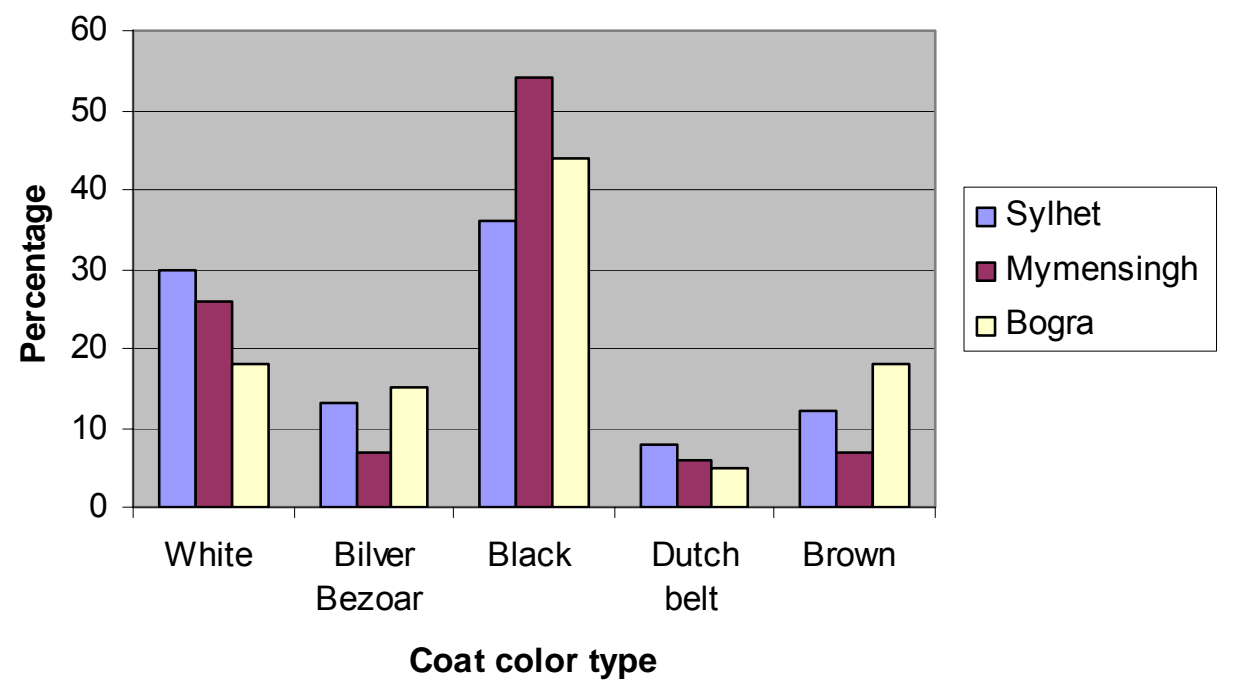

Fig. 1. Coat Color Distribution of Goats in Different Experimental sites. 


\section{Body weight and body measurements}

Body weights and measurements of the goats in different regions, coat color and sex are exposed in Table 1. It revealed that the live weight of the goats at 12-month, body length at $18-$ and $\geq 24$-month $(p$ $<0.001)$, heart girth at 18 -month $(p<0.01)$ and $\geq 24$-month $(p<0.001)$ and height at wither at 9-month $(p<0.05)$ and 18-month $(p<0.001)$ differed from one area to another. Body weights and measurements of the goats at other stages were found almost similar in all the regions. Heart girth at 6-and 12-month also affected $(p<0.05)$ by coat color. It was also found that the value of heart girth among coat colors followed the manner of Black>White>Silver Bezoar. White type goats showed higher height at wither at 9- and 12month compared to other groups. In the age of 3 to 12 months, White and SB type goats were found consistently heavier than Black goats but body length of SB always ranked the lowest and Black type was in between except at 6-month age group. Live weight of SB goats in each stage was very close to that of White goats. All respective values of males (whether) consistently exceeded $(p<0.001)$ females at all ages. Effect of coat color on the body weight between 3- and 12-month and body length at 12-month in this study was similar to the observations of Alam (2006) and Hasanat et al. (2003) who found higher body weight in White type goat compared to Black type at the given ages. Heights at wither in coat color groups, in the present study, at 12-month of age were found slightly lower than what were reported by Husain et al. (2008 and 2005) and Alam (2006). Heavier White type goats, because of their higher distribution percentage (30\%), might bring about the regional difference in live weight of goats in Sylhet at 12 months. The differences in the parameters at the present effort also might be due to variation in breed, genetic constitution, physical condition of the animals, agro-climatic condition, nutritional level and other management attributes reported by Rahman (2007).

\section{Hair diameter and hair density}

Goats of Mymensingh had coarser hair at 9-month $(p<0.05)$ and 12-month $(p<0.01)$ than that of Sylhet and Bogra (Table 2). This might be due only to mere chance or sampling fluctuation. Hair diameter of White, SB and Black goats varied significantly in a consistent fashion at 9 - and 18-month $(p<0.001)$ and 12 -month $(p<0.01)$ of age. Table 3 shows that hair density of flank and thigh region differed $(p<0.01)$ between coat color groups and mean differences were very large. Higher number of hairs/sq. inch was found both at flank and thigh region in BB goat. Nevertheless, hair of lower density/sq. inch was found at flank and thigh in White type goat. It interprets that White type goat had coarsest hair with the lowest density/unit area and Black goats had finest hair with highest density and the position of SB was intermediate. Hair measurement of the present attempt in coat color types was higher than those recorded in the study of Alam (2006). Results strongly provide evidence that the hair diameter and density can be a typical characteristic to distinguish goats of different coat color. Lower hair density might have some adaptive significance of the White goats to tropical hot and humid environment conducive to body heat dissipation.

\section{Behavior of goat}

Table 4 shows the behavioral pattern of different coat color group of goat. Herding tendency, rain bath, resting preference, foraging habit, pre-weaning mortality and disease susceptibility were scored between 0 and 5 as obtainable from the opinion of the farmers. Coat color had significant effect $(p<0.001)$ on herding tendency, rain bath, resting preference, foraging habit, pre-weaning mortality, disease susceptibility, highest number of kidding in life time. Goats of White coat color had higher herding tendency. Score of rain-bath was almost similar in Black and SB type goat. White type goats have higher preference for resting in crowdy place among coat color groups. Overall feeding habit was higher in Black goat than in White and SB type goats. The highest value of forage selectivity habit in White goat and the lowest value in Black goat were observed. Pre-weaning mortality and disease susceptibility were higher in Black coated goats but SB goats and White goats had lower score for the same ethological characteristic. White goats lived for a longer period of time and had higher average maximum kidding number than other two groups. Alam (2006) reported that the herding tendency of White and Black type goat was slightly higher than the observations of current study. Average rain bath of White and Black type goats and tendency of the former for resting in crowdy place were found higher than the results of Alam (2006). Preweaning mortality, disease susceptibility and maximum life span (year) of White and Black goats were found higher than the result of Alam (2006) who found the indices to be 0.4, 0.1and 9.1and 1.1, 1.6 and 7.7 in White and Black type goats. Number of kidding in lifetime in this study was found higher in White and lower in Black coated goats than the reports of Alam (2006). 
Table 1. Body weight and body measurements of goats by region, coat color and sex

\begin{tabular}{|c|c|c|c|c|c|c|c|c|c|c|c|c|c|c|c|c|c|c|c|}
\hline \multirow{3}{*}{$\begin{array}{l}\text { Factor } \\
\text { Month }\end{array}$} & \multirow{2}{*}{\multicolumn{4}{|c|}{ Body weight $(\mathrm{kg})$ at month }} & \multicolumn{15}{|c|}{ Body measurements $(\mathrm{cm})$} \\
\hline & & & & & \multicolumn{5}{|c|}{ Body length } & \multicolumn{5}{|c|}{ Heart girth } & \multicolumn{5}{|c|}{ Height at wither } \\
\hline & 3 & 6 & 9 & 12 & 6 & 9 & 12 & 18 & $\geq 24$ & 6 & 9 & 12 & 18 & $\geq 24$ & 6 & 9 & 12 & 18 & $\geq 24$ \\
\hline \multicolumn{20}{|l|}{ Region } \\
\hline Sylhet & 4.16 & 6.53 & 10.49 & $13.66^{\mathrm{a}}$ & 58.91 & 62.00 & 67.03 & $74.13^{\mathrm{a}}$ & $77.64^{\mathrm{b}}$ & 49.84 & 53.14 & 55.57 & $60.82^{\mathrm{a}}$ & $65.25^{\mathrm{a}}$ & 39.29 & 41.35 & 45.61 & $47.69^{c}$ & 50.72 \\
\hline Mymensingh & 4.15 & 6.31 & 10.34 & $13.15^{\mathrm{b}}$ & 58.98 & 62.08 & 66.31 & $72.02^{\mathrm{C}}$ & $75.73^{\mathrm{c}}$ & 49.77 & 52.73 & 55.42 & $59.31^{\mathrm{c}}$ & $64.88^{\mathrm{b}}$ & 39.10 & 42.00 & 45.48 & $48.59^{b}$ & 51.17 \\
\hline Bogra & 4.15 & 6.30 & 10.30 & $13.24^{\mathrm{b}}$ & 59.18 & 63.43 & 67.38 & $72.45^{\mathrm{b}}$ & $78.52^{\mathrm{a}}$ & 49.72 & 53.21 & 56.21 & $59.93^{b}$ & $62.43^{\mathrm{c}}$ & 39.36 & 42.39 & 45.54 & $49.71^{a}$ & 51.73 \\
\hline Level of. Sig. & NS & NS & NS & $* * *$ & NS & NS & NS & $* * *$ & $* * *$ & NS & NS & NS & ** & $* * *$ & NS & * & NS & $* * *$ & NS \\
\hline \multicolumn{20}{|l|}{ Coat colour } \\
\hline White & $4.33^{\mathrm{a}}$ & $6.73^{\mathrm{a}}$ & $10.78^{a}$ & $13.95^{\mathrm{a}}$ & $59.30^{b}$ & $63.29^{a}$ & $67.60^{\mathrm{a}}$ & $74.07^{\mathrm{a}}$ & $78.02^{\mathrm{a}}$ & $49.84^{b}$ & 52.87 & $55.14^{b}$ & 59.91 & 64.40 & 39.53 & $42.39^{a}$ & $46.14^{a}$ & 48.65 & 51.19 \\
\hline Black & $3.39^{b}$ & $5.97^{\mathrm{b}}$ & $9.93^{c}$ & $12.74^{\mathrm{c}}$ & $59.66^{a}$ & $63.06^{b}$ & $67.31^{\mathrm{b}}$ & $73.94^{\mathrm{b}}$ & $77.97^{\mathrm{a}}$ & $52.20^{\mathrm{a}}$ & 53.43 & $56.94^{\mathrm{a}}$ & 60.42 & 64.88 & 39.24 & $41.17^{\mathrm{C}}$ & $45.47^{b}$ & 48.67 & 50.98 \\
\hline Silver Bezoar & $4.23^{\mathrm{a}}$ & $6.58^{\mathrm{a}}$ & $10.40^{b}$ & $13.65^{\mathrm{b}}$ & $58.05^{c}$ & $61.29^{c}$ & $65.74^{\mathrm{c}}$ & $71.36^{\mathrm{c}}$ & $75.71^{\mathrm{b}}$ & $49.36^{\mathrm{c}}$ & 52.72 & $54.80^{\circ}$ & 60.08 & 64.45 & 38.90 & $41.63^{b}$ & $45.08^{c}$ & 47.87 & 51.07 \\
\hline Level of. Sig. & $* * *$ & $* * *$ & $* * *$ & $* * *$ & ** & ** & $* * *$ & $* * *$ & $* * *$ & * & NS & * & NS & NS & NS & $* *$ & * & NS & NS \\
\hline \multicolumn{20}{|l|}{ Sex } \\
\hline Male & 4.43 & 6.80 & 10.86 & 13.88 & 60.31 & 64.43 & 69.01 & 75.59 & 78.93 & 50.95 & 54.35 & 56.94 & 61.84 & 66.07 & 40.22 & 43.04 & 47.56 & 50.09 & 52.75 \\
\hline Female & 3.96 & 6.17 & 10.14 & 13.18 & 58.10 & 61.43 & 65.74 & 71.75 & 76.93 & 49.08 & 42.31 & 54.80 & 59.27 & 63.75 & 38.66 & 41.02 & 44.73 & 47.63 & 50.27 \\
\hline Level of. Sig. & $* * *$ & $* * *$ & $* * *$ & $* * *$ & $\star * *$ & $\star \star * *$ & $* \star *$ & $* * *$ & $\star \star * *$ & $* * *$ & $* * *$ & $* * *$ & $* \star *$ & $* * *$ & $* * *$ & $* * *$ & $* * *$ & $* * *$ & $* * *$ \\
\hline
\end{tabular}

${ }^{*}=p<0.05,{ }^{* *}=p<0.01,{ }^{* * *}=p<0.001$

$\mathrm{NS}=$ Non-significant

${ }^{a b c}$ means with different superscripts in the same column differed significantly 
Table 2. Hair diameter of goats as affected by region, coat color and sex at particular age

\begin{tabular}{|c|c|c|c|c|c|c|}
\hline \multirow[t]{2}{*}{ Factor } & \multicolumn{6}{|c|}{ Hair diameter $(\times 0.1 \mathrm{~mm})$} \\
\hline & $\mathrm{n}$ & 9-month & $\mathrm{n}$ & 12-month & $\mathrm{n}$ & 18-month \\
\hline \multicolumn{7}{|l|}{ Region } \\
\hline Sylhet & 25 & $2.54 \pm 0.04^{\mathrm{C}}$ & 24 & $2.78 \pm 0.03^{c}$ & 23 & $3.08 \pm 0.03$ \\
\hline Mymensingh & 25 & $2.70 \pm 0.06^{a}$ & 26 & $2.00 \pm 0.05^{\mathrm{a}}$ & 26 & $3.10 \pm 0.04$ \\
\hline Bogra & 23 & $2.62 \pm 0.06^{b}$ & 25 & $2.82 \pm 0.03^{b}$ & 24 & $3.05 \pm 0.03$ \\
\hline Level of Sig. & & * & & ** & & NS \\
\hline \multicolumn{7}{|l|}{ Coat Color } \\
\hline White & 22 & $2.80 \pm 0.04^{a}$ & 20 & $3.08 \pm 0.04^{a}$ & 20 & $3.20 \pm 0.04^{\mathrm{a}}$ \\
\hline Black & 31 & $2.60 \pm 0.03^{\mathrm{C}}$ & 35 & $2.80 \pm 0.03^{c}$ & 36 & $2.98 \pm 0.02^{\mathrm{C}}$ \\
\hline Silver Bezoar & 20 & $2.73 \pm 0.04^{b}$ & 20 & $2.92 \pm 0.03^{b}$ & 19 & $3.13 \pm 0.03^{b}$ \\
\hline Level of Sig. & & $* * *$ & & ** & & *** \\
\hline \multicolumn{7}{|l|}{ Sex } \\
\hline Male & 32 & $2.72 \pm 0.04$ & 30 & $2.89 \pm 0.02$ & 31 & $3.12 \pm 0.04$ \\
\hline Female & 41 & $2.50 \pm 0.02$ & 43 & $2.73 \pm 0.02$ & 42 & $3.03 \pm 0.03$ \\
\hline Level of Sig. & & $* * *$ & & $* * *$ & & ** \\
\hline
\end{tabular}

${ }^{*}=p<0.05,{ }^{* *}=p<0.01,{ }^{* * *}=p<0.001$

NS=Non-significant, $n=$ number of observation

${ }^{a b c}$ means with different superscripts in the same column differed significantly

Table 3. Effect of different factors on hair density

\begin{tabular}{|l|c|c|c|c|}
\hline \multirow{2}{*}{ Factor } & \multicolumn{4}{|c|}{ Hair density/sq. inch } \\
\cline { 2 - 5 } & $\mathrm{n}$ & Flank & $\mathrm{n}$ & Thigh \\
\hline Coat color & 12 & $820.10 \pm 19.30^{\mathrm{c}}$ & 12 & $970.00 \pm 25.40^{\mathrm{c}}$ \\
\hline White & 20 & $980.65 \pm 35.90^{\mathrm{a}}$ & 20 & $1210.20 \pm 37.27^{\mathrm{a}}$ \\
\hline Black & 11 & $910.20 \pm 30.00^{\mathrm{b}}$ & 11 & $1110.25 \pm 34.25^{\mathrm{b}}$ \\
\hline Silver Bezoar & ${ }^{* *}$ & ${ }^{* *}$ \\
\hline Level of Sig. & \multicolumn{5}{|l|}{} \\
\hline Sex & $860.80 \pm 31.00$ & 20 & $1008.71 \pm 38.25$ \\
\hline Male & 20 & $960.50 \pm 60.22$ & 23 & $1120.40 \pm 50.42$ \\
\hline Female & 23 & $* * *$ & ${ }^{* * *}$ \\
\hline Level of Sig. & \multicolumn{5}{|l|}{}
\end{tabular}

${ }^{* *}=p<0.01,{ }^{* * *}=p<0.001, n=$ number of observation

${ }^{a b c}$ means with different superscripts in the same column differed significantly

Table 4. Behaviour (Ethology) of White, Black and Silver Bezoar type of goats

\begin{tabular}{|l|c|c|c|c|c|c|c|}
\hline Character & $\mathrm{n}$ & White & $\mathrm{n}$ & Black & $\mathrm{n}$ & Silver Bezoar & $\begin{array}{c}\text { Level of } \\
\text { significance }\end{array}$ \\
\hline Herding Tendency (0-5) & 53 & $3.64 \pm 0.015^{\mathrm{a}}$ & 52 & $1.31 \pm 0.010^{\mathrm{c}}$ & 43 & $1.91 \pm 0.017^{\mathrm{b}}$ & ${ }^{* * *}$ \\
\hline Rain Bath (0-5) & 53 & $1.57 \pm 0.021^{\mathrm{b}}$ & 52 & $3.54 \pm 0.012^{\mathrm{a}}$ & 43 & $3.53 \pm 0.015^{\mathrm{a}}$ & ${ }^{* * *}$ \\
\hline Resting in Crowdy Place (0-5) & 53 & $3.75 \pm 0.016^{\mathrm{a}}$ & 52 & $1.31 \pm 0.012^{\mathrm{c}}$ & 43 & $2.00 \pm 0.020^{\mathrm{b}}$ & ${ }^{* * *}$ \\
\hline Foraging Habit & 53 & $2.55 \pm 0.014^{\mathrm{c}}$ & 52 & $4.10 \pm 0.010^{\mathrm{a}}$ & 43 & $3.70 \pm 0.014^{\mathrm{b}}$ & ${ }^{* * *}$ \\
\hline Overall (0-5) & 53 & $3.77 \pm 0.011^{\mathrm{a}}$ & 52 & $1.37 \pm 0.013^{\mathrm{c}}$ & 43 & $1.87 \pm 0.014^{\mathrm{b}}$ & ${ }^{* * *}$ \\
\hline Selectivity (0-5) & 53 & $1.57 \pm 0.013^{\mathrm{c}}$ & 52 & $3.65 \pm 0.010^{\mathrm{a}}$ & 43 & $2.70 \pm 0.019^{\mathrm{b}}$ & ${ }^{* * *}$ \\
\hline Pick Low Quality Grasses (0-5) & 53 & $1.06 \pm 0.015^{\mathrm{b}}$ & 52 & $2.21 \pm 0.010^{\mathrm{a}}$ & 43 & $1.28 \pm 0.019^{\mathrm{b}}$ & ${ }^{* * *}$ \\
\hline Pick Grasses from Marshy Land (0-5) & 53 & $0.40 \pm 0.01^{\mathrm{c}}$ & 52 & $1.33 \pm 0.013^{\mathrm{a}}$ & 43 & $1.14 \pm 0.017^{\mathrm{b}}$ & ${ }^{* * *}$ \\
\hline Pre-weaning Mortality (0-5) & 53 & $0.38 \pm 0.010^{\mathrm{c}}$ & 52 & $1.71 \pm 0.016^{\mathrm{a}}$ & 43 & $1.12 \pm 0.030^{\mathrm{b}}$ & ${ }^{* * *}$ \\
\hline Disease Susceptibility (0-5) & 53 & $9.28 \pm 0.032^{\mathrm{a}}$ & 52 & $7.48 \pm 0.018^{\mathrm{c}}$ & 43 & $7.88 \pm 0.035^{\mathrm{b}}$ & ${ }^{* * *}$ \\
\hline Maximum life Span (year) & 53 & $13.30 \pm 0.044^{\mathrm{a}}$ & 52 & $10.54 \pm 0.025$ & 43 & $10.35 \pm 0.048^{\mathrm{c}}$ & ${ }^{* * *}$ \\
\hline Highest number of kidding in life time & & & & & & & $\mathrm{b}$ \\
\hline
\end{tabular}

$* * *=p<0.001$

NS=Non-significant, $n=$ number of observation

${ }^{a b c}$ means with different superscripts in the same row differed significantly 
Table 5. Milk yield ( g/day) and litter size of White type, Black and Silver Bezoar type of goats ${ }^{@}$

\begin{tabular}{|l|c|c|c|c|}
\hline \multirow{2}{*}{ Coat color } & \multicolumn{2}{|c|}{ Per day milk production (g/day) } & \multicolumn{2}{c|}{ Litter size } \\
\cline { 2 - 5 } & $\mathrm{n}$ & Mean \pm SE & $\mathrm{n}$ & Mean \pm SE \\
\hline White & 28 & $366.84 \pm 3.19^{\mathrm{a}}$ & 21 & $2.00 \pm 0.138$ \\
\hline Black & 33 & $248.83 \pm 2.19^{\mathrm{c}}$ & 29 & $2.05 \pm 0.120$ \\
\hline Silver Bezoar & 23 & $274.16 \pm 6.83^{\mathrm{b}}$ & 28 & $1.93 \pm 0.101$ \\
\hline Level of significance & & ${ }^{* *}$ & & NS \\
\hline
\end{tabular}

${ }^{* *}=p<0.01, N S=$ Not significant $(p>0.05)$

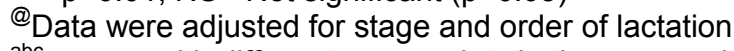

${ }^{a b c}$ means with different superscripts in the same column differed significantly

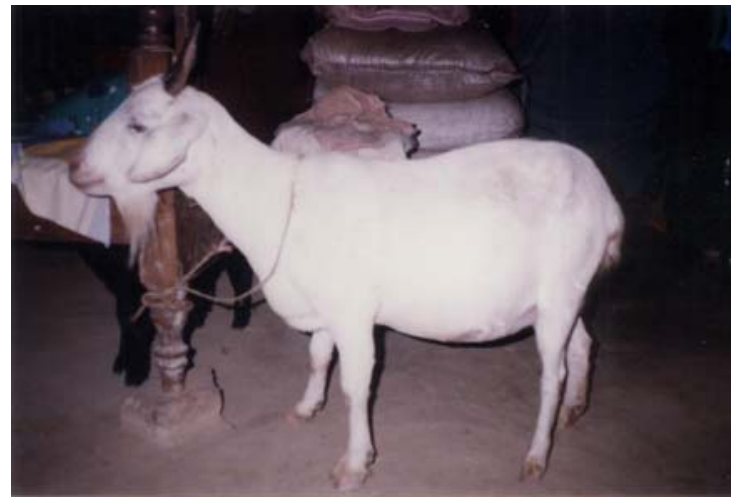

Photograph 1. White type doe

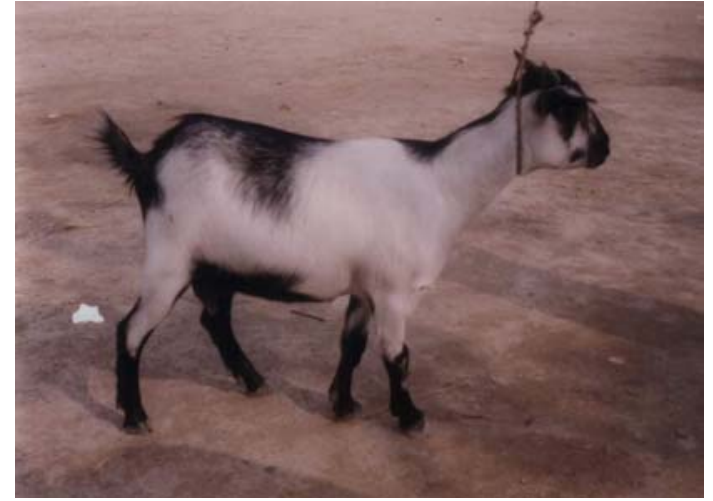

Photograph 2. Silver Bezoar type doe

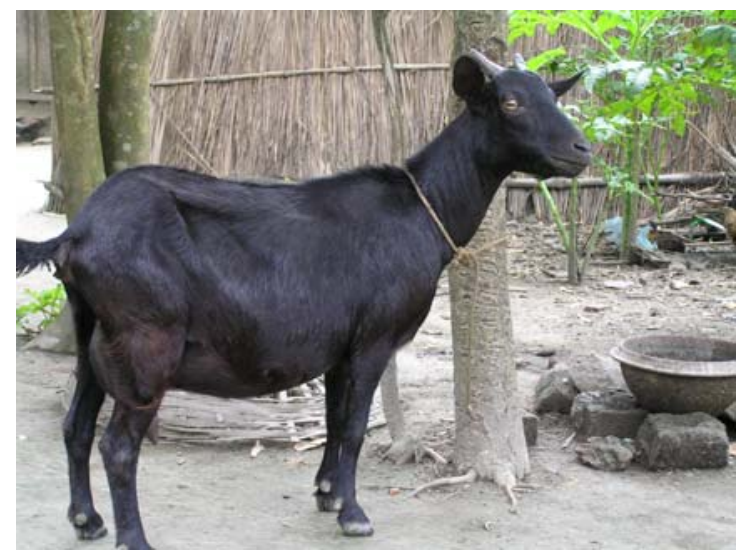

Photograph 3. Black type doe

As the White and SB type goats are more preferential in choosing the best quality forages, less willing to receive rain bath, have less pre-weaning mortality and diseases susceptibility and have longer life span, so they can be regarded superior to Black coated goat. From adaptability view point White and SB goats show higher efficiency than does Black coated goats.

\section{Average daily milk production}

Table 5 shows the average milk production $(\mathrm{g} / \mathrm{d})$ of different type of goats adjusted for lactation order and stage. Milk yield was significantly $(p<0.001)$ highest in White goat and lowest in Black goat. Average milk yield in the present study was higher than reports of Alam (2006) and lower than that of Chowdhury and Faruque (2001). Higher milk yield of White and SB type goat might contribute in higher live weight of kids and lower kid mortality in pre-weaning stage. 


\section{Litter size}

Coat color showed no significant $(p>0.05)$ effect on litter size of goats. No variation was found among the groups (Table 5). Average litter size (parity adjusted) of White, SB and Black does were 2.00 \pm 0.138 , $1.93 \pm 0.101$ and $2.05 \pm 0.120$, respectively. It follows that an increase in the proportion of White type goats in the BB population may enhance production potential without affecting litter size and other production profiles apart from maintenance of biodiversity.

\section{Conclusion}

From the results of the present study it may be concluded that White and Silver Bezoar types of Black Bengal goat are superior to Black coated members. Much attention is required for characterization, evaluation of performance and effective conservation in situ to save them from extinction. Molecular genetic characterization of the White and Silver Bezoar type of Black Bengal goats is needed to find their finer differences amongst them.

\section{Acknowledgement}

Authors are thankful to Bangladesh Agricultural University Research System for funding the research project (Project No. 2005/32/AU).

\section{References}

Alam M.K. 2006. Characterization and performance evaluation of white goat in some selected areas of Bangladesh. M. S. Thesis, Department of Animal Breeding and Genetics, Bangladesh Agricultural University, Mymensingh.

Amin M.R. 2000. Genetic improvement of production traits in Black Bengal goat by selective breeding and cross breeding. Ph.D thesis, Bangladesh Agricultural University, Mymensingh.

Chowdhury S.A and Faruque S. 2001. Feeding Black Bengal goat under intensive management: Milk Feeding in pre weaned kids. Asian-Australasian Journal of Animal Sciences 17:39-45.

FAO. 2003. FAO Production Year Book. Food and Agriculture Organization of the United Nations, Rome, Italy. Vol. 57: $210-231$.

FAO. 2007. The State of the World's Animal Genetic Resources. Food and Agriculture Organization of the United Nations, Rome, Italy.

Farque M.O and Khondaker M.A.M.Y. 2007. Recent Advances of Goat Genotyping in Bangladesh. Genotyping for Breed and Type Determination. In: Proceeding of the Workshop on Recent Advances of Livestock Genotyping in Bangladesh: Genotyping of Goats and Buffaloes for Breed Type Determination, held on May 10, 2007 in BARC, Dhaka, Bangladesh, pp28- 40.

Hasanat M.T, Husain S.S, Amin M.R and Mia G. 2003. Characterization of Black Bengal goats for some qualitative and quantitative traits. Bangladesh Journal of Animal Science 21: 109-120.

Husain S.S and Amin M.R. 2003. Genetic resource conservation and utilization: Participatory maintenance of Animal Genetic Resource at rural level in Bangladesh. In: Workshop organized by FAO and Ministry of Livestock and Fisheries, Govt. of Bangladesh, BLRI, Savar, Dhaka.

Husain S.S, Munim T, Khandoker M.A.M.Y and Islam M.R. 2005. Morphometric differences among different sub-populations of Black Bengal goat. Progressive Agriculture 16: 83-89.

Husain S.S, Amin M.R, Khandoker M.A.M.Y and Zarate A.V. 2008. Black Bengal-potential goat genetic resources for Bangladesh. Proceedings of $15^{\text {th }}$ Int'l congress on biotechnology in animal reproduction held in. Bangladesh Agricultural University, Mymensingh on 6-7 Aug. 2008.

Nozawa , K., Katsumata, M, Hasnath ,MA, Mostafa, KG and Faruque MO. 1984. Coat color polymorphism in the Black Bengal Goat. In Genetic Studies on Breed Differentiation of the Native Domestic Animals in Bangladesh. Research Report, Tokyo University of Agriculture, 87-99.

Rahman A.H.M.S. 2007. Morphometric characterizations of Black Bengal buck. M. S. Thesis, Department of Animal Breeding and Genetics, Bangladesh Agricultural University, Mymensingh. 